\title{
How Ecotourism Works at the Community-Level: the Case of Whale-Watching in the Azores
}

\section{Luís Silva}

Centre for Research in Anthropology (CRIA/FCSH-UNL), Portugal, luis.silva98@gmail.com

in: Current Issues in Tourism, 2015, Vol. 18, N. ${ }^{\circ}$ 3, 196-211, DOI: 10.1080/13683500.2013.786027, http://www.tandfonline.com -- please cite published version --

\begin{abstract}
Whale-watching is one of the fastest growing tourism industries worldwide, often viewed as a sustainable, non-consumptive strategy for the benefits of cetacean conservation and the coastal communities, alternative to and incompatible with whaling. Yet there is paucity of research on how things actually work out at the community-level. Drawing on research literature and my own ethnographic fieldwork, this article bridges a knowledge gap in this field while examining an Azorean context where tourism has brought a re-commodification of the whale for the community (observing wildlife as opposed to harpooning it) in the last 20 years. The analysis is focused on the four main community-level implications: governance of common maritime resources, and tourism's contribution to economic sustainability, cultural identity and social relations. It is shown that whale-watching, as any other form of community-based ecotourism, is not a panacea that always promotes biodiversity conservation and economic and sociocultural sustainability for the host communities. Moreover, expanding on the theorisation of emerging institutional fields by Lawrence and Phillips, the political, historical, economic and sociocultural context of the community involved is a key factor for understanding local agency and the local specific features of new fields.
\end{abstract}

Keywords Whale-watching; community-based tourism; impact; governance; sustainability; whaling

\section{Aims, Rationale and Methods}

Whale-watching means "tours by boat, air or from land, formal or informal, with at least some commercial aspect, to see, swim with, and/or listen to any of the some 83 species of whales, dolphins and porpoises" (Hoyt, 2001, p. 3) in the wild. Whale-watching is one of the fastest growing (eco)tourism industries globally, and has expanded rapidly throughout the last two decades, both in terms of demand and of supply. Hoyt (1995, 2001) notes that the number of whale-watchers and of countries involved in the activity increased, respectively, from 4 million and 31 in 1991 to 9 million and 87 in 1998, while the number of communities offering whale-watching tours increased from 295 in 1994 to 492 in 1998. In 2008, figures increased to 13 million whale-watchers and 119 countries (O'Connor et al., 2009).

This swift growth in whale-watching tourism and the global potential for it to expand (Cisneros-Montemayor et al., 2010) reflect a change in attitude towards whales that occurred in urban Western societies in the late twentieth century, illustrative of the political character of nature (e.g. Latour, 2004; Macnaghten and Urry, 1998). On the one hand, the perception of whales has changed from "edible commodities to sacrosanct symbols of nature" (van Ginkel, 2007, p. 399). In the process, an image of a "superwhale", a non-existing mythical creature, was created (Kalland, 1993). Lawrence and Phillips (2004) show that this image of whales is strongly influenced by popular culture, 
of which Hollywood film series Free Willy is a good example. In their view, this represents a global shift in public perceptions, one that humanizes whales, forcing us to reconsider the ethics of whaling (while creating space for the emergence of whalewatching (see below and also Wearing, Buchmann and Jobberns, 2011)). However, this perception of whales is not shared by all (Brydon, 2006; Cunningham, Huijbens and Wearing, 2012; Kalland, 1993; Ris, 1993).

At the same time, since the International Whaling Commission global moratorium on commercial whaling was enacted in 1986 as a strategy to protect whales from the threat of extinction, whale-watching has been increasingly propagated as the best way to exploit cetaceans. Actually, there is a growing argument for it to replace commercial whaling in maritime communities and countries still engaged in the activity, such as Norway, Iceland and Japan (e.g. Higham and Lusseau, 2008; Hoyt and Hvenegaard, 2002; Kuo, Chen and McAleer, 2012; Orams, 2001; Parsons and Rawles, 2003; Parsons and Draheim, 2009; WWF, 2003), although some authors (Cunningham, Huijbens and Wearing, 2012; Moyle and Evans, 2008) claim that both activities could and/or should co-exist in the same territory.

Environmental non-governmental organizations support whale-watching on the grounds that observation induces conservation; whale-watching boats enable the carrying out of research; viewing free whales is preferable to watching captive animals; and whale-watching precludes whaling, providing a viable economic alternative to it (Corkeron, 2004, pp. 847-848; see also Epstein, 2008; Neves-Graça, 2010). In 1998, the International Whaling Commission summarised the benefits of whale-watching as follows: "it offers new development opportunities for coastal communities"; "it can provide substantial economic benefits"; "it is a sustainable, non-consumptive use of cetaceans offering opportunities for non-lethal research"; and "it offers opportunities for education and for development of research methods" (vide O'Connor et al., 2009, p. 19).

In this perspective, whale-watching appears aligned with ecotourism, commonly defined as a threefold strategy - providing nature-based attractions, education opportunities, and ecological, economic and socio-cultural sustainability - for the benefits of biodiversity conservation and the local communities (e.g. Fennel, 2001; Goodwin, 1996; West and Carrier, 2004). Actually, as Cunningham, Huijbens and Wearing (2012, p. 153) note, "[a]ligning whale-watching with ecotourism is the most common rhetoric employed to promote the practice as a sustainable one", although "precisely how remains contested".

This debate is exacerbated by two factors. First, the extent to which whalewatching is low-impact and non-consumptive is questionable. Although research has shown that certain wildlife species can habituate to the regular presence of humans (Young, 1998), there is concern that whale-watching might be detrimental to the target species, potentially causing it injuries and death by collisions with boats or yet behavioural changes because of the intensity, noise and conduct of boat traffic (e.g. Constantine, Brunto and Dennis, 2004; Hoyt, 2005; Lusseau and Higham, 2004; Scarpaci and Parsons, 2012). The introduction of regulating guidelines is a method commonly used to mitigate this impact (e.g. Carlson, 2012; Garrod and Fennel, 2004), but of course compliance with them is not guaranteed (e.g. Parsons, 2012; Quiros, 2007).

From a more critical perspective, in a paper presented at the Global Conference on Non-Consumptive Utilization of Cetacean Resources held in Boston, USA, in 1983, Jamieson and Regan (quoted in Benson, 2010, p. 162) argued that to frame humancetaceans relations as of "use" deserves "moral scepticism" and that our ethical 
responsibility is simply to "let whales alone": "Just as whales are not here for us to kill for our purposes, they are not here for to us 'to study', or 'to watch', or to "play with"'. According to Ris (1993), the non-consumptive utilization of whales is part of an urban Western project promoting cultural imperialism. Neves-Graça (2010) also considers spurious the claim that whale-watching is non-consumptive as it is associated with a mode of production characteristic of the late capitalist society in which whales are transformed into a new type of commodity as providers of ecological services.

Second, although research into this topic is still in its infancy, the extent to which whale-watching benefits host communities has been questioned by some researchers. Much like the above quoted International Whaling Commission, many supporters of whale-watching, including scientists and environmental organisations (e.g. Hoyt, 1995, 2001; Hoyt and Hvenegaard, 2002; IFAW, 1999; O'Connor et al., 2009; Orams, 2001, 2002; Parsons et al., 2003; Wilson and Tisdell, 2003; WWF, 2003), claim that it provides a number of benefits to maritime communities, such as income growth through the creation of new jobs and businesses in tourism-related activities, a sense of identity and pride.

Nevertheless, research in the Atlantic and the Pacific has shown that whalewatching fails to deliver promises of community-level economic benefits and has plenty of other social impacts, some of which carrying negative dimensions (Moyle and Evans, 2008; Neves-Graça, 2004, 2006, 2010; Ris, 1993; see also Quiros, 2005). When NevesGraça (2010) compared two distinct whale-watching business models in the Atlantic (Azores and the Canary Islands), she further noted that distinct business models produce distinct impacts.

In the meantime, while Norway, Iceland and Japan continue to hunt whales, invoking cultural resource rights or scientific inquiry, many traditional whaling communities have moved from the contested debate on the merits of whaling versus whale-watching towards embracing whale-watching as both an emerging cultural and economically sustainable product.

In addition, in recent times a number of strategies have been implemented to arrest the decline of biodiversity. One of these strategies has been to encourage local communities to join in conservation initiatives and this has caused, in some cases, conflicts with the development aspirations of those communities (Blangy and Mehta, 2006; Clerici et al., 2007). With whale-watching we are faced with the same issues, as now this has become an industry and the question is how to bridge the gap between the needs of conservation and the aspirations of profit by local communities. It is maintained that at the local level development approaches to tourism based on sustainability will only succeed if local communities see tangible benefits (Wunder, 2007 ) as is the case for whale-watching. Following Kiss's (2004) conceptualisation of community-based ecotourism (CBET), Wearing, McDonald and Ponting (2005) suggest that this is a strategy that has been advocated as an enterprise-based conservation approach where the natural environment is maintained and is used to protect biodiversity and to generate economic benefits for the local communities.

My purpose is to provide an ethnographically-informed contribution on the implications of the whale-watching industry for communities traditionally engaged in commercial whaling. The main question is: What are the main community-level shifts entailed by the new use of cetaceans? Pursuing this question in an Azorean destination where tourism has brought in recent decades a re-commodification of the whale for the community, this article sheds light on how ecotourism development via whale-watching actually works out at the community-level. Hence, it also contributes to the study of community-based ecotourism. 
After a brief outline of the local context and background, this article puts forward an analysis of the constitution of a specific new institutional field and of the four main community-level implications: governance of common maritime resources, as well as tourism's contribution for economic sustainability, cultural identity and social relations.

The contribution is based on ethnographic materials collected via literature research and my own anthropological fieldwork - including participant observation, detailed fieldnotes and a set of two dozens of (recorded) semi-structured, informal interviews with stakeholders and residents - conducted in Lajes do Pico in July-August 2011.

\section{Context and Background}

Lajes is the eldest of three municipalities in the island of Pico, which was first populated by the Portuguese during the fifteenth century. Today a village of 400 inhabitants, a parish of 1,800 people and a municipality of 4,700 inhabitants (numbers for 2011) Lajes is in various ways an instance of the socioeconomic change that rural areas of the Azores have been undergoing in the last 150 years. First, as population censuses show, the number of this municipality's inhabitants has decreased $57 \%$ between 1864 and 2011, while the largest percentage of population loss has occurred in the last six decades (42\%) and the lowest number of inhabitants was recorded in 2011.

Second, inhabitants depended on an extremely precarious subsistence economy including a sustainable exploitation of oceanic resources until the 1980s. During a whole century, a set of whale products provided money to relieve poverty among a large part of the population who practiced a local variation of nineteenth century American whaling focused on sperm whales (e.g. Fowler, 1970; Neves-Graça, 2004). In Lajes, there were 22 canoes, navigated by 98 men and owned by seven commercial whaling companies. Plus, a whale-processing factory near the local port functioned between 1955 and 1983, when Portugal signed the Bern Convention. Although whaling was declining since the 1950s (e.g. Venables, 1969), whalers resisted the termination of their activity, particularly in the island of Pico and most especially in Lajes.

In the last four decades but especially since the 1990s, along with the decline of agriculture, Lajes has witnessed the rise of economic activities linked to the secondary and, mainly, tertiary sectors, in which public/municipal administration and tourism occupy prominent places. Tourism relies now in natural resources and human-whales relations, including whale-watching activities and cultural representations of whale hunting.

\section{The Emergence of Whale-Watching in Lajes and Governance Issues}

In their study of whale-watching in the West coast of Canada, Lawrence and Phillips argue that the emergence of this activity was made possible through the influence of macro-cultural discourse on whales upon local actors in the creation of new institutional fields. The re-conceptualization of whales in North America, along with the

characteristics of the geographically distinct institutional fields that emerged depended on local action and the processes of structuration that those actions supported. The constitution of specific new fields required interested actors to engage in the institutional innovation and isomorphism that produced the unique networks of relationships and sets of institutions that constituted those fields (Lawrence and Phillips, 2004, p. 689). 
This theoretical framework provides a useful tool to describe the case of Lajes, where institutional processes and purposeful action by individual actors, both locals and foreigners, interpreting local discourse and the global re-conceptualisation of whales, constituted a specific new institutional field. The idea of implementing whale-watching in the Azores emerged in 1987, at the primary instigation of a European parliament deputy of the Azores and the International Fund for Animal Welfare; at that time, supported by funding from the European Community and the Regional Government of the Azores, that organisation came to the archipelago to investigate the potential for whale-watching in order to create a source of income and employment alternative to whaling, having concluded that the potential for that was high (c.f. O'Connor et al., 2009, pp. 13-14). Research conducted in more recent years confirms that potential, as 28 species of cetaceans were reported alive in the Azores' waters (e.g. ICES, 2010).

Meanwhile, whale-watching started in Lajes in the early 1990s, through the initiative of a French citizen in his thirties connected to the recreational marine. He started the business in partnership with his wife, an Azorean architect. In 1991, they settled in the village and, with the help of a spotter previously engaged in whaling and supported by the municipal government, began to offer watching tours focused on sperm whales, using a sailboat, later replaced by a small inflatable boat. In few years, the initiative has generated an annual flow of a few thousands of tourists to the village/island. In the terms of Lawrence and Phillips (2004), the success of the "institutional entrepreneur" has stimulated "institutional isomorphism" by locals and, thereby, the constitution of a specific new institutional field including whales- and dolphins-watching tours and swimming-with-dolphins programmes. Support from the Regional Government and the European Community/Union played a decisive role.

Higham and Lusseau (2004, p. 177) note that "historically", whale-watching regulation "has been developed retrospectively". This is the case of the Azores. As the number of whale-watching boats (and companies) has increased in the area in the 1990s, especially in Pico and the neighbouring island of Faial, so the need to regulate the activity to avoid the overcrowding of cetaceans' environment with boats and tourists has emerged (Neves-Graça, 2004, p. 295). Regulations were implemented in 1999 and successively revised in 2003, 2004 and 2005, and include guidelines on platforms, approach distances, angle of approach, duration of interaction, maximum number of boats allowed per group of animals, a limited number of licenses and specifications on the maximum size of boats (see Carlson, 2012, pp. 152-155; ICES, 2010, p. 158).

Research into the ecological impact of this activity in the Azores has shown opposite results. While some studies (Magalhães et al., 2002; Magalhães et al., 2007, op. cit. in ICES, 2010, p. 159) concluded that whale-watching has minimal effects on the target species, others (Neves-Graça, 2004, p. 295, 2010, pp. 731-732; Visser et al., 2010) concluded that the harmful effect is considerable. An issue repeatedly noted in the research literature is the difficulty faced by regional authorities in implementing regulation. In the early 2000s, Magalhães et al. (2002, p. 273) observed that only 54\% of the boats completely complied with the guidelines when targeting sperm whales. More recently, scientists have shown concern for the limited enforcement of regulation and violations regularly observed in the region, especially off Pico Island (where boats departing from Lajes, Madalena, also in Pico, and Horta, in Faial, often converge) and during swimming-with-dolphins activities (ICES, 2010, p. 6; K. Hartman, interviewed in 2011). To change the situation, scientists have recommended the implementation of an efficient law-enforcement scheme (ICES, 2010, pp. 6, 162).

In Lajes, stakeholders claim for the need of an effective management of maritime resources, taking also into consideration current concerns associated with climate 
change in the archipelago, since there is an increasingly higher unpredictability of weather and climate (cf. Sakakibara, 2011, p. 76), or the potential implications of global climate changes for the sustainability of the whale-watching industry (Lambert et al., 2010).

Two main factors help us to understand the lack of effectiveness of the existing regulations. First, as Neves-Graça (2010) notes, whale-watching businesses are in essence capitalist enterprises whose goals may be, and quite often are, distinct from the objectives of conservation, as is the case in many other forms of ecotourism worldwide (e.g. Cater and Lowman, 1994; Isaacs, 2000; Quiros, 2005; West and Carrier, 2004). This collision of interests is evident, for example, in the words of an informant during conversation at the port:

Legislation says that only two people are allowed to swim with dolphins in the same area. I take five or six tourists on board to swim. I cannot put two of them in the waters and not the others, for they all have paid the activity already and they all want to swim with dolphins. This is even more complicated when tourists are going back home the next day, and don't have another opportunity to do it (Field journal, August 2011). ${ }^{1}$

Second and mainly, a set of circumstances contributed to turn whale-watching into an arena of social competition and conflict between individuals and social groups with diverging views/interests over the same resource. As Higham and Lusseau (2004, p. 171) note, understanding and managing the ecological impacts of whale-watching tourism activities requires attention to the political and sociocultural context of the destination.

It is noteworthy that whale-watching regulation entailed a radical change in the governance of natural resources within the community of Lajes, particularly the transition from a regime of free access to local cetacean resources to a regime in which access to these commons is regulated by the state. As Neves-Graça $(2004,2006)$ shows, the constitution of this new form of resource governance entailed two main dimensions: bureaucratic settings, informed by science and international law, and the local level, informed by a century of actual engagement with whaling. These two dimensions came into conflict regarding how to regulate whale-watching to protect cetaceans' welfare and how to shape the whale-watching business model to guarantee economic sustainability for the community. Although local dissident companies were able to incorporate some traditional ecological knowledge into the disciplinary measures adopted for the activity in the region, and both local and scientific ecological knowledge have contributed to knowledge formation through friction, they were less influential in shaping legislation (Neves-Graça, 2004, 2006).

More than a decade has passed since these differences generated conflict in Lajes for the first time. But divergent views on how to design and to practice whale-watching persist. In particular, there is no agreement regarding the whale-watching business model, and whether it should remain low volume and for elite consumption, or else pursue higher volume and a more popular consumption - although mass tourism is not on the horizon of inhabitants due to the limited availability of flights to the island, to its low tourist accommodation capacity and short tourism season (cf. Neves-Graça, 2010, p. 735). While some stakeholders claim that whale-watching must remain a privilege of few people to better safeguard the animals, others contend that families have the right to experience whale-watching and so provide income to more locals, with reflection on 
prices. As the institutional entrepreneur noted while commenting the situation of the tour operators' association of the Azorean archipelago,

We founded the association to promote research and produce legislation and supervision on whale-watching in the Azores. I worked 10 years in the project and then I killed the baby in a month. I was elected president in 2004, but the association disappeared. We have quite different visions on tourism. The idea was to limit the number of licenses to 15 instead of the current 23 , and consider 12 or, at the best, 20 as the maximum number of people on board. But this is now over; there are no guidelines on the subject and we already have boats for up to 80 people in São Miguel and in the future in the Azores it will happen much like in other countries, such as Canada and the Canary Islands, where there are boats for up to 200 or 300 people. This is not environmentally sustainable; animals do not tolerate such pressure. In my view, whale-watching should remain a privilege for a few people, an elite market, not a cheap market for the masses (Field journal, July 2011).

The words of this informant also give evidence to Lawrence and Phillips's (2004, p. 690) formulation that in the production of new institutional fields, "strategic action by powerful local actors plays an important role", even though "fields are highly emergent in that their final form is unintended by any actor". The characteristics of the local tourism economy help us to better understand the case.

\section{Local Tourism Economy}

As has been the case of many other destinations (e.g. Parsons and Rawles, 2003; Parsons and Draheim, 2009), whale-watching has put Lajes into the international tourism system (Neves-Graça, 2006, p. 22). In Lajes, the number of whales-watchers has increased from 50 in 1991 to 4,000 in 1997 and an estimated 12,000 in 2011. They are not a homogeneous group; for example, there are many whale-watchers repeating the experience and children. However, the average whale-watcher is a foreign city dweller from a member-state of the European Union (especially from Southern and Northern countries), relatively young (aged between 35 and 45 years old), has high education levels and a managerial or scientific occupation, goes whale-watching for the first time and visits the island with family and/or friends (cf. Oliveira, 2005, pp. 41-42). On a quick look, this profile is similar to that of whale-watchers in many other destinations worldwide (e.g. Parsons et al., 2003).

There is no question that the arrival of tourists has brought important flows of capital to Lajes and the Pico Island, fostering the creation of new jobs and businesses in tourism-related services. What is questionable is whether these benefits accrue to the whole community of Lajes, or to a large part of it. With reference to the late 1990s, Neves-Graça (2010, p. 733) argues that whale-watching creates "new forms of exploitative class relations and uneven distribution of profits", and contests the community-level benefits associated with whale-watching in the discourse of environmental non-governmental organizations:

While cetourism has attracted large numbers of tourists to the island, the first few people who invested in whale watching were able to benefit from an advantageous position where they quickly made profits that allowed them to invest in parallel economic activities [...]. As a result, much of the money that cetourists spend stays mostly in the hands of [the first] company and a rival company that was founded at around the same time. Finally, because of its seasonality, most people who work in 
whale watching are forced to live on welfare during the off season. This includes not only those who work directly for whale watching operations but also for the hotels and restaurants (Neves-Graça, 2010, p. 736).

More than a decade has elapsed since the author conducted her fieldwork. Since it is nowadays widely accepted in the research literature that tourism is a dynamic activity that requires longitudinal research to assess its evolution and impacts with higher precision (e.g. Butler, 2009, for tourism in general; Peake, 2011, for the case of whalewatching), and given the highly emergent nature of new institutional fields (Lawrence and Phillips, 2004), the question now is whether the situation has changed or not and how.

At present, the ownership of three of four whale-watching companies is familybased; boats (nine of 10, most of which are fast Zodiac inflatable models for up to 12 passengers) are often owned by a couple, two of which are foreigners and one is local. This, for example, is the case of the institutional entrepreneur who also explores accommodations and a restaurant in the village during the season, while his wife is a secondary school teacher. Another is that of a local entrepreneur in his early thirties, son of one of three co-founders of the first local company in 1997, exploring, with the help of his wife, a family-based bakery and other businesses during the year. The first company hosts an average of 5,500 whale-watchers per year, about $45 \%$ of those estimated for 2011; two other companies account for much of the remaining share, besides a local artisan of whalebone and ivory and also a tourism entrepreneur in her early forties who uses since 2004 a small boat from a company based in another island.

Locally, whale-watching is the main economic activity for four individuals, the institutional entrepreneur and three workers in their thirties. Each firm employs an average of six people directly, including crew (skippers and mariners) and personal on shore (spotters and shopkeepers), usually for six or less months. Most workers are locals, but there are some incomers (mainly young, both male and female), especially from mainland Portugal, France and the Netherlands, including trainees. During off season, some workers undertake occupations in public administration, livestock, fishery, or supermarkets, others live on unemployment benefits and others yet have no source of income.

Indirectly, along with the whaling heritage which has developed in parallel (see below), whale-watching acted as a catalyst for tourism. In the parish of Lajes, there are five snack-bars/restaurants, five cafés, four accommodation units offering a total of 52 rooms, two craftwork shops, two museums (the Whaler's Museum inaugurated in 1988 and the Whale-Processing Factory Museum inaugurated in 2008) and a tourist office. On a nearby parish, there is also a small hotel, three restaurants and two cafés, and plans to build a spa. In the municipality, there is an additional offer of about 50 rooms in private houses that, off season, are rented out to secondary school teachers, for example. Few of these businesses were created before the re-commodification of the whale.

Museums and the tourist office are state-owned. Other businesses are owned, in some cases, by whale-watching entrepreneurs who invested in parallel activities to maximize benefits during the season (Neves-Graça, 2010). In other cases, however, they are owned by different entrepreneurs, both locals and newcomers. Overall, the dominant profile of these entrepreneurs is similar to the one of the whale-watching companies' owners. In total, tourism occupies in the municipality an estimated 50 workers on a continuous basis, plus 100 on a seasonal basis, usually low-paid.

Thus, notwithstanding the existence of changes, the situation remains largely similar to the one observed by Neves-Graça, especially with regard to the limited 
contribution of the activity for the community's economic sustainability. Inhabitants bluntly acknowledge and resent this situation, viewed as one major difference between whale hunting and whale-watching. The idea that wealth associated with whalewatching flows mainly to a small number of entrepreneurs while the one associated with whale hunting flowed to a large part of the population is a recurring refrain in the inhabitants' discourses:

Whale-watching is more profitable than whale hunting was, but does not provide money to everyone as before. Whale-watching is a very good business but for the companies' owners. They earn a fortune by selling tickets for 50 Euros and then pay a pittance to the employees. For example, [the first operator] had no place to drop dead when he arrived here, he was poor [...], and he got rich in a few years. So, participants now have different revenues; during whale hunting, whalers earned the same amount of money (Ex-whaler and former whale-watching worker, during interview).

However, inhabitants tend to express a positive view on whale-watching and whale-watchers and on tourism and tourists generally. This, for example, is the case of a local tourism entrepreneur in his mid-thirties:

Whales and tourism keep this village alive, as tourists provide dynamics to restaurants, accommodations, cafés, museums and whale-watching operators. But this is only for three months in the year; in winter, the village becomes desert-like.

Accordingly, the mayor of Lajes stated during an interview at his office that

Tourism is a strategic area of development in the municipality. [...] I do not have exact figures, but the tourism sector (including whale-watching, restaurants, lodgings, museums...) provides income and employment to a number of people.

\section{The "Second Life" of Whale Hunting}

Van Ginkel (2007, pp. 399, 402-403) notes that the contemporary (urban) Western swing in attitude towards whales has led to negative stereotyping and stigmatization of whalers: "At present, whales, not whalers, are heroes of popular culture", and "whereas whales are humanized, whale hunters are demonized as savage beasts". Kalland (1993) further argues that in the anti-whaling discourse, whales are converted into totems, thus dividing mankind into "good guys" (whales' protectors/lovers) and "bad guys" (whalers and whale eaters). This has echoed in the late twentieth century in Lajes, as its whalers were treated as murderers of whales in the international mass media and by environmental organisations (Neves-Graça, 2006, p. 23). But this is only part of the story.

In parallel with the termination of whale hunting in the archipelago, a "second life" emerged for this activity and its' practitioners (the whale hunters) as "heritage", as described by Kirshenblatt-Gimblett (1998, pp. 149-151), that is, as "representations of themselves" and of the proper community within a tourism economy. This reflects a change in the meaning of whaling. In the past, it was an economic activity associated with poverty and the better-off tried to distance themselves from that practice and the sociocultural meaning of whaling; now, instead, it stands for an honourable epic venture of the past referred to a culturally specific collective identity, and also a major tourist attraction. 
This is remarkably evident in Lajes, a village also known as the Whaling Village where representations of whale hunting proliferate: along with two museums, there is a monument, various land-based lookouts, a former house of whaling canoes, five former whaling canoes regularly involved in regattas, craftworks, the Week of Whalers annual feast... Lajes is the core part of a tourist route of whale hunting heritage that includes several communities in Pico Island formerly engaged in the activity. In the process, exwhale hunters, of which 18 still live in the parish, received a romantic image "fed by sentimental and heroic reports of the hardships whalers endured in their man-to-animal struggles" (van Ginkel, 2007, p. 398). In the Azores, fictional literature played a critical role in the construction of this image, especially the books by Dias de Melo (19252008), himself an ex-whaler (e.g. 1988 [1964]). As the then mayor of Lajes wrote in the local newspaper $O$ Dever in February 2003,

The most valuable heritage that whaling ever had in our village is the human heritage: the whalers; these fearless and brave men of the sea. They were always forgotten, always ignored, especially when in the epoch of their full activity, very few, if any, of those people who today write high praise on the whalers of the time had felt proud to be relative of a whaler, perhaps because, socially, they felt ashamed of that.

Contrary to what one might think, the aesthetic appreciation of whales is not by any means a new phenomenon in Lajes. As Neves-Graça $(2005$, p. 7) argues, whaling involved a multilevel communication process between the hunters and their prey imbued with aesthetic dimensions: "[e]cological aesthetics in particular can never be about the detached appreciation of arbitrarily dissected and located aspects of partwhole relations (as in whale watching and its effort to 'see' how beautiful whales are)". The idea that cetaceans are animals that humans are supposed to use only by nonmaterial means (e.g. viewing instead of hunting), although present in younger generations, makes no sense for many people, especially for ex-whale hunters and fishermen. In their view, whales and dolphins are part of a wide set of natural resources upon which their livelihood depends, along with tuna fish and cows, for example, all of which deserve equal respect and concern by humans.

And yet, nowadays in the Azores there are no ideas of resuming whaling, for two main reasons. First, it is a practice viewed as pertaining to the past, while living in the present in the form of heritage, as noted above, and contributing as such to forge modern social, economic, cultural and religious life (cf. Sakakibara, 2011). Second, whale-watching is more profitable than was whaling and the inhabitants believe that the harvesting of cetaceans would adversely affect the demand for whale-watching and tourism generally.

\section{Host-Host Relationships}

Although tourism impact studies often ignore host-host relations, evidence suggests that tourism development has a strong effect on social relations within the community involved (Cohen, 1984; Harrison, 2001; Schellhorn, 2010; Silva, 2009). In Lajes, whale-watching is a major arena of social competition and conflict among stakeholders with reflections on social relations, including local interpersonal ones. The detrimental effect of whale-watching on social relations was almost immediate. As Neves-Graça (2004, 2006) shows, the structuration of the new institutional field was marked by public antagonist relations between stakeholders since the beginning; in the process, the 
institutional entrepreneur, who was warmly received by the population in early years, became persona non grata for many people, including most ex-whale hunters.

During fieldwork in 2011, I observed that the image of the first operator has not changed since within the community, and that public antagonist relations between people with competing interests/views over the same resource persist, while other have emerged thereof. The inhabitants continue to resent the fact that a foreigner founded the first whale-watching company, has endeavoured to regulate it by the standards of scientific ecological knowledge to the detriment of the traditional one, and reached an upper social and economic position by exploring a natural resource that locals were used to have free access to and to govern in an autonomous way. In addition, they also resent more recent attitudes regarding whale-watching, access to and governance of oceanic commons, and local development issues.

Actually, whale-watching is often a strong tension-generator and a very competitive activity. There is tension and competition between companies' owners/entrepreneurs and workers at the various stages of activity, from spotting cetaceans at the ocean from land-based lookouts (competition between spotters) to approaching the target species (competition between boats) and also recruiting clients (competition between entrepreneurs/shopkeepers). And competition is often fairly intense and translates into a form of rivalry among stakeholders.

Of course, mainly through informal networks, whale-watching is at the origin of some more or less lasting collaboration and cooperation links, and coalitions, mainly between operators, travel agencies and other tourism-related actors, or amongst team members, but also between different operators, for instance through occasional transfers of clients and information about the localisation of cetaceans. Furthermore, there are cases in which competition between companies is crossed by kinship and friendship ties, mainly amongst workers. However, relationships between the competitors are marked by tension and conflict. The abovementioned tour operators' association is a good example.

The highly competitive nature of the industry is a reflection not only of the scarcity of economic resources but also of the characteristics of social relations within the community. Anthropologists (e.g. Campbell, 1964; Cole, 1991; Cutileiro 1971; Pina-Cabral, 1986) have showed that envy and competition for resources and social prestige are characteristics of social relations in face-to-face societies, including European peasantries and coastal communities. In a small, face-to-face community like that of Lajes, competition is therefore almost inevitable, and the relationships between competitors have always entailed ambivalence and some degree of tension (see NevesGraça, 2004, p. 294; Melo, 1988 [1964]), for competition within whale hunting).

\section{Conclusions}

The purpose of the article was to provide an ethnographically-informed examination of how ecotourism works out at the community-level, with reference to whale-watching in an Azorean context where tourism has brought in the last two decades a recommodification of the whale for the community, as observing wildlife replaces harpooning it.

My research has shown strong evidence that whale-watching is not a magic formula that always benefits cetacean conservation and the host populations as some advocators might have us believe. With regard to conservation, although the whale is no longer hunted, activities such as whale-watching and swimming with dolphins are not always benign for the target species. This happens not only because the practices of whale-watching businesses are more dictated by short-term profit goals than 
environmental concerns (Neves-Graça, 2010, pp. 725, 736-737), but also due to a set of circumstances that helped to determine the characteristics of the new institutional field.

As in the Canadian context studied by Lawrence and Phillips (2004), here the emergence of whale-watching was made possible through institutional processes and the agency of powerful individuals interpreting local discourse and the Western reconceptualisation of whales. Although "institutional entrepreneurship" was carried out by a foreigner, the constitution of the new field required local actors to engage in "institutional isomorphism". Moreover, as the strategic action by local actors plays an important role in the emergence of new institutional fields (Lawrence and Phillips, ob. cit.), so the political, historical, economic and sociocultural context of the community involved is a key factor for understanding local agency and the local specific features of the new fields.

At the community-level, the re-commodification of the whale has had both positive and negative effects. On the one hand, it has helped to foster the foundation of a culturally-specific collective identity, or a uniqueness of place, strongly associated with whales and human-whales relations in which cultural representations of whale hunting occupy a prominent place. Notwithstanding its seasonal nature, it has also promoted income growth to some people, both locals and foreigners, through the creation of new jobs and businesses in tourism-related activities.

On the other hand, it has brought an increased community's involvement into wider frameworks (national and international systems) and a consequent loss of autonomy, as the welfare of the community became more dependent on external factors over which it has no control, as is usual in tourism economies (Greenwood, 1976; Cohen, 1984). It has also created a perceived loss of influence in the management of marine natural resources on which the livelihood of inhabitants depends. There was a shift from a situation of free access to cetaceans to another in which access to these commons is regulated by the state, and locals played a marginal role in designing the new form of governance (Neves-Graça, 2004, 2006).

Furthermore, whale-watching failed to accomplish promises of community's economic and sociocultural sustainability. First, as is the case of many other ecotourism destinations worldwide (e.g. Kiss, 2004; Kruger, 2005; Quiros, 2005; Schellhorn, 2010; West and Carrier, 2004), it has created "new forms of exploitative class relations and uneven distribution of profits" (Neves-Graça, 2010, p. 733). Second, as is also usual in tourist destinations, it gave rise to a new arena of social competition and conflict between interested actors/social groups that affects social cohesion. There are persistent disagreements over how to govern the maritime resources to better protect animals and how to explore the whale-watching industry to guarantee the community's economic sustainability.

Plus, whale-watching is often a strong tension-generator and an intense competitive activity which translates into a form of rivalry between stakeholders. While the competitive nature of this industry is partly a result of the scarcity of economic resources, it also reflects the characteristics of social relations in small, face-to-face communities where envy and competition for resources and social prestige are commonplace. In my view, the effects and intensity of competition around whalewatching could be relieved through collaborative action between all stakeholders aiming at the adoption of better management practices and a more equitable distribution of profits for all participants.

The lesson we learn from Lajes can also be taken into consideration in the worldwide debates about conservation and commercialization of maritime resources. The question scientists, policy-makers and tourism industry leaders are facing is how to 
determine the conditions under which whale-watching becomes harmful to the animals at stake, and how to best protect them (e.g. Catlin, Jones and Jones, 2012; Carlson, 2012; Higham and Lusseau, 2004; Parsons, 2012; Parsons and Woods-Ballard, 2003; Simmonds and Isaac, 2007; Steckenreuter, Harcourt and Möller, 2012; Visser et al., 2010). Here is evidence that the regulations which many are currently seeking to introduce may not work in communities like this, given its internal tensions.

As communities living in close contact with the natural resources play key roles in their management (e.g. Agrawal, 2003; Ostrom, 1990), it seems critical to increase local involvement in the experiential micro-politics and ethics of governance of common maritime resources, and to develop a critical awareness amongst community members of the social and ecological costs of purely "profit-oriented" decision-making and practices. This could involve explicit ethical and social agendas for change that value place and belonging in local communities. In the main, this power shift in resource management will depend on the political and historical context of the community involved. How governance is being practiced locally is a factor that should be taken into consideration to examine how much appropriate change can be achieved and whether locals will resist and challenge, say, conservation-based global politics.

But the case of Lajes can also be taken into account in the global debates on conservation and development. Friend (1992), for example, doubts that resource conservation is compatible with economic development, while other authors (e.g. Isaacs, 2000; West and Carrier, 2004) question the compatibility of environmental conservation with ecotourism in particular. The divide between sustainable development and sustainable tourism development is explored elsewhere (e.g. Butler, 1999; Sharpley, 2010). Community-based ecotourism has been advocated as a strategy to overcome the conflicting needs of resource conservation and the aspirations of profit by local communities (Kiss, 2004; Wearing, McDonald and Ponting, 2005). This case study demonstrates that this strategy is not necessarily efficient, as the tension between conservation and development persists in community-based forms of ecotourism such as whale-watching.

\section{Notes}

1 All materials in other languages were translated by the author.

\section{Acknowledgements}

The study was made possible by a fellowship from the Portuguese Foundation for Science and Technology (SFRH/BPD/34229/2006). I am grateful to this institution for the support. I am also grateful to the two anonymous Current Issues in Tourism reviewers for their work. Special thanks go out to the inhabitants of Lajes for their contribution to this study.

\section{References}

Agrawal A. (2003) Sustainable governance of common-pool resources: context, methods, and politics. Annual Review of Anthropology, 32, 243-62.

Benson, E. (2010) Wired Wilderness: Technologies of Tracking and the Making of Modern Wildlife. Baltimore: the John Hopkins University Press.

Blangy, S. and Mehta, H. (2006) Ecotourism and ecological restoration. Journal for Nature Conservation, 14 (3-4), 233-236.

Brydon, A. (2006) The predicament of nature: Keiko the whale and the cultural politics of whaling in Iceland. Anthropological Quarterly, 79 (2), 225-260. 
Butler, R. (1999) Sustainable tourism: A state-of-the-art review. Tourism Geographies: An International Journal of Tourism Space, Place and Environment, 1 (1), 7-25.

Butler, R. (2009) Tourism in the future: cycles, waves or wheels? Futures, 41, 346-352.

Campbell, J. (1964) Honour, Family and Patronage: A Study of Institutions and Moral Values in a Greek Mountain Community. Oxford: Oxford University Press.

Carlson, C. (2012) A Review of Whale Watching Guidelines and Regulations around the World, version 2012; http://iwcoffice.org/cache/downloads/4mc4x7y9nlicc8g0wwg00cg0c/WWREGS\%2 02012.pdf. Accessed December 2012.

Cater, E. and Lowman, G. (2004) (eds.) Ecotourism: A Sustainable Option? Chichester: John Wiley \& Sons.

Catlin, J., Jones, T. and Jones, R. (2012) Balancing commercial and environmental needs: licensing as a means of managing whale shark tourism on Ningaloo reef. Journal of Sustainable Tourism, 20 (2), 163-178.

Cisneros-Montemayor, A., Sumaila, U., Kaschner, K. and Pauly, D. (2010) The global potential for whale-watching. Marine Policy, 34 (6), 273-278.

Clerici, N., Bodini, A., Eva, H., Gregoire, J., Dulieu, D. and Paolini, C. (2007) Increased isolation of two Biosphere Reserves and surrounding protected areas (WAP ecological complex, West Africa). Journal for Nature Conservation, 15, 2640.

Cohen, E. (1984) The sociology of tourism: approaches, issues, and findings. Annual Review of Sociology, 10, 373-392.

Cole, S. (1991) Women of the Praia. Work and Lives in a Portuguese Coastal Community. Princeton, NJ: Princeton University Press.

Constantine, R., Brunto, D. and Dennis, T. (2004) Dolphin-watching tour boats change bottlenose dolphin (Tursiops truncatus) behaviour. Biological Conservation, 117, 299-307.

Corkeron, P. (2004) Whale watching, iconography, and marine conservation. Conservation Biology, 18 (3), 847-849.

Cunningham, P., Huijbens, E. and Wearing, S. (2012) From whaling to whale watching: examining sustainability and cultural rhetoric. Journal of Sustainable Tourism, 20 (1), 143-161.

Cutileiro, J. (1971) A Portuguese Rural Society. Oxford: Clarendon Press.

Epstein, C. (2008) The Power of Words in International Relations: Birth of an AntiWhaling Discourse. Cambridge, MA: The MIT Press.

Fennell, D. (2001) A content analysis of ecotourism definitions. Current Issues in Tourism, 4 (5), 403-421.

Fowler, R. (1970) The Hunt. Narrated by Joseph Wiseman. RLF production.

Friend, A. (1992) Economics, ecology and sustainable development: are they compatible? Environmental Values, 1 (2), 157-170.

Garrod, B. and Fennel, D. (2004) An analysis of whalewatching codes of conduct. Annals of Tourism Research, 31 (2), 334-352.

Goodwin, H. (1996) In pursuit of ecotourism. Biodiversity and Conservation, 5, 277 291.

Greenwood, D. (1976) Tourism as an agent of change: a Spanish Basque case. Annals of Tourism Research, 3 (3), 128-142.

Harrison, D. (2001) Afterword. In D. Harrison (ed.), Tourism and the Less Developed World: Issues and Case Studies (pp. 251-263). New York: CAB International. 
Higham, J. and Lusseau, D. (2004) Ecological impacts and management of tourist engagements with cetaceans. In R. Buckley (ed.), Environmental Impacts of Ecotourism (pp. 171-186). Cambridge, MA: CABI Publishing.

Higham, J. and Lusseau, D. (2008) Slaughtering the goose that lays the golden egg: are whaling and whale-watching mutually exclusive? Current Issues in Tourism, 11 (1), 63-74.

Hoyt, E. (1995) The Worldwide Value and Extent of Whale-Watching: 1995. Bath, UK: Whale and Dolphin Conservation Society.

Hoyt, E. (2001) Whale-watching 2001. Worldwide Tourism Numbers, Expenditures, and Expanding Socioeconomic Benefits. Yarmouth, MA: IFAW.

Hoyt, E. (2005) Sustainable ecotourism on Atlantic Islands, with special reference to whale-watching. Marine protected areas and sanctuaries for cetaceans. Biology and Environment: Proceedings of the Royal Irish Academy, 105B (3), 141-154.

Hoyt, E. and Hvenegaard, G. (2002) A review of whale-watching and whaling with applications for the Caribbean. Coastal Management, 30, 381-399.

ICES (International Council for the Exploration of the Sea) (2010) Report of the Working Group on Marine Mammal Ecology. Horta: ICES.

IFAW (International Fund for Animal Welfare) (1999) Report of the Workshop on the Socioeconomic Aspects of Whale-watching: Kaikoura, New Zealand. Yarmouth, MA: IFAW.

Isaacs, J. (2000) The limited potential of ecotourism to contribute to wildlife conservation. The Ecologist, 28 (1), 61-69.

Kalland, A. (1993) Management by totemization: Whale symbolism and the antiwhaling campaign. Arctic, 46 (2), 124-133.

Kirshenblatt-Gimblett, B. (1998) Destination Culture: Tourism, Museums, and Heritage. Berkeley, Los Angeles and London: University of California Press.

Kiss, A. (2004) Is community-based ecotourism a good use of biodiversity conservation funds? Trends in Ecology and Evolution, 19 (5), 232-237.

Kruger, O. (2005) The role of ecotourism in conservation: panacea or pandora's box? Biodiversity and Conservation, 14 (3), 579-600.

Kuo, H., Chen, C. and McAleer, M. (2012) Estimating the impact of whaling on global whale-watching. Tourism Management, 33 (6), 1321-1328.

Latour, B. (2004) Politics of Nature: How to Bring the Sciences into Democracy (translated by C. Porter). Cambridge, MA: Harvard University

Lambert, E., Hunter, C., Pierce, G. and MacLeod, C. (2010) Sustainable whale watching tourism and climate change: towards a framework of resilience. Journal of Sustainable Tourism, 18 (3), 409-428.

Lawrence, T. and Phillips, N. (2004) From Moby Dick to Free Willy: macrocultural discourse and institutional entrepreneurship in emerging institutional fields. Organization, 11 (5), 689-711.

Lusseau, D. and Higham, J. (2004) Managing the impacts of dolphin-based tourism through the definition of critical habitats: the case of bottlenose dolphins (Tursiops spp.) in Doubtful Sound, New Zealand. Tourism Management, 25 (6), 657-667.

Macnaghten, P. and Urry, J. (1998) Contested Natures. London: Sage.

Magalhães, S. Prieto, R., Silva, M., Gonçalves, J., Afonso-Dias, M. and Santos, R. (2002) Short-term reactions of sperm whales (Physeter macrocephalus) to whalewatching vessels in the Azores. Aquatic Mammals, 28 (3), 267-274.

Melo, D. (1988) [1964] Dark Stones. Providence, RI: Gávea-Brown Publications. 
Moyle, B. and Evans, M. (2008) Economic development options for island states: the case of whale-watching. Shima: The International Journal of Research into Island Cultures, 2 (1), 41-58.

Neves-Graça, K. (2004) Revisiting the tragedy of the commons: ecological dilemmas of whale-watching in the Azores. Human Organization, 63 (3), 289-300.

Neves-Graça, K. (2005) Chasing whales with Bateson and Daniel. Australian Humanities Review, 35, 1-9; http://www.australianhumanitiesreview.org/archive/Issue-June-2005/katja.html Accessed July 2011.

Neves-Graça, K. (2006) Politics of environmentalism and ecological knowledge at the intersection of local and global processes. Journal of Ecological Anthropology, 10, 19-32.

Neves-Graça, K. (2010) Cashing in on cetourism: a critical ecological engagement with dominant E-NGO discourses on whaling, cetacean conservation, and whalewatching. Antipode, 42 (3), 719-741.

O'Connor, S., Campbell, R., Cortez, H. and Knowles, T. (2009) Whale-watching Worldwide: Tourism Numbers, Expenditures and Expanding Economic Benefits. Yarmouth, MA: IFAW.

Oliveira, C. (2005) A Actividade de Observação Turística de Cetáceos no Arquipélago dos Açores. Contribuição para o seu Desenvolvimento Sustentável. Unpublished Master Dissertation in Management and Nature Conservation. Ponta Delgada: University of the Azores.

Orams, M. (2001) From whale hunting to whale watching in Tonga: a sustainable future? Journal of Sustainable Tourism, 9 (2), 128-146.

Orams, M. (2002) Marine ecotourism as a potential agent for sustainable development in Kaikoura, New Zealand. International Journal of Sustainable Development, 5 (3): 338-354.

Ostrom E. (1990) Governing the Commons: the Evolution of Institutions for Collective Action. Cambridge, MA: Cambridge University Press.

Parsons, E. (2012) The negative impacts of whale-watching. Journal of Marine Biology. Doi:10.1155/2012/807294. Accessed September 2012.

Parsons, E. and Rawles, C. (2003) The resumption of whaling by Iceland and the potential negative impact in the Icelandic whale-watching market. Current Issues in Tourism, 6 (5), 444-448.

Parsons, E. and Draheim. M. (2009) A reason not to support whaling - a tourism impact case study from the Dominican Republic. Current Issues in Tourism, 12 (4), 397403.

Parsons, E., Warburton, C., Woods-Ballard, A., Hughes, A. and Johnston, P. (2003) The value of conserving whales: the impacts of cetacean related tourism on the economy of rural West Scotland. Aquatic Conservation: Marine and Freshwater Ecosystems, 13, 397-415.

Parsons, E. and Woods-Ballard, A. (2003) Acceptance of voluntary whalewatching codes of conduct in West Scotland: the effectiveness of governmental versus industry-led guidelines. Current Issues in Tourism, 6 (2), 172-182.

Peake, S. (2011) An industry in decline? The evolution of whale-watching tourism in Hervey Bay, Australia. Tourism in Marine Environments, 7 (3-4), 121-132.

Pina-Cabral, J. (1986) Sons of Adam, Daughters of Eve. The Peasant Worldview of the Alto Minho. Oxford: Clarendon Press. 
Quiros, A. (2005) Whale shark 'ecotourism' in the Philippines and Belize: evaluating conservation and community benefits. Tropical Resources: Bulletin of the Yale Tropical Resources Institute, 24, 42-48.

Quiros, A. (2007) Tourist compliance to a code of conduct and the resulting effects on whale shark (Rhincodon typus) behavior in Donsol, Philippines. Fisheries Research, 84, 102-108.

Ris, M. (1993) Conflicting cultural values: whale tourism in Northern Norway. Arctic, 46 (2), 156-163.

Sakakibara, C. (2011) Whale tales: people of the whales and climate change in the Azores. Focus on Geography, 54 (3), 75-90.

Scarpaci, C. and Parsons, E. (2012) Recent advances in whale-watching research: 20102011. Tourism in Marine Environments, 8 (3), 161-171.

Schellhorn, M. (2010) Development for whom? Social justice and the business of ecotourism. Journal of Sustainable Tourism 18 (1), 115-135.

Sharpley, R. (2000) Tourism and sustainable development: exploring the theoretical divide. Journal of Sustainable Tourism, 8 (1), 1-19.

Silva, L. (2009) Casas no Campo. Etnografia do Turismo Rural em Portugal. Lisbon: Imprensa de Ciências Sociais.

Simmonds, M. and Isaac, S. (2007) The impacts of climate change on marine mammals: early signs of significant problems. ORYX, 41(1), 19-26.

Steckenreuter, A., Harcourt, R. and Möller, L. (2012) Are speed restriction zones an effective management tool for minimizing impacts of boats on dolphins in an Australian marine park? Marine Policy, 36, 258-264.

Visser, F., Hartman, K., Rood, E., Hendriks, A., Zult, D., Wolff, W., Huisman, J. and Pierce, G. (2010) Risso's dolphins alter daily resting pattern in response to whalewatching at the Azores. Marine Mammal Science, 27 (2), 366-381.

van Ginkel, R. (2007) Touching creature, sensing nature: the sensorial consumption of cetaceans. In R. van Ginkel and A. Strating (eds.), Wildness \& Sensation: Anthropology of Sinister and Sensuous Realms (pp. 398-419). Apeldoorn: Het Spinhuis.

Venables, B. (1969) Baleia!, Baleia!: Whale Hunters of the Azores. New York: Alfred Knopf.

Wearing, S., McDonald, M. and Ponting, J. (2005) Building a decommodified research paradigm in tourism: the contribution of NGOs. Journal of Sustainable Tourism, 13 (5), 424-439.

Wearing, S., Buchmann, A. and Jobberns, C. (2011) Free Willy: the whale-watching legacy. Worldwide Hospitality and Tourism Themes, 3 (2), 127-140.

West, P. and Carrier, J. (2004) Ecotourism and authenticity: getting away from it all? Current Anthropology, 45 (4), 483-498.

Wilson, C. and Tisdell, C. (2003) Conservation and economic benefits of wildlife based tourism: sea turtles and whales as case studies. Human Dimensions of Wildlife, 8, 49-58.

Wunder, S. (2007) The efficiency of payments for environmental services in tropical conservation. Conservation Biology, 21 (1), 48-58.

WWF (World Wide Fund) (2003) Whale Watching: A Future for Whales?; available at http://www.panda.org. Retrieved December 2012.

Young, K. (1998) Seal Watching in the UK and Republic of Ireland. UK: IFAW. 